\title{
Type of Leaderships, Accountability, Public Participation and Transparency of Public Policy as moderation to Degree of Legislative's Members Budgeting Knowledge in Controlling the Regional Budget (APBD)
}

\author{
Aprianto L. Kuddy ${ }^{1}$ \\ aprianto kuddy@yahoo.com
}

\begin{abstract}
The purpose of this research was to examine the influence of the quality of board of the council knowledge about budget and the control board of the council on Regional Budget (APBD) with leadership types, accountability, participation and public policy transparency as the moderating variables that strengthen or weaken the relationship. Independent variable of this research is quality of board of the council knowledge about budget and the control board of the council on Regional Budget (APBD) as a dependent variable.

The analysis of this research was a member of the board council at Regional Representative Council (DPRD) of Papua Province, Regional Representative Council (DPRD) of Jayapura Regency and Regional Representative Council (DPRD) of Jayapura Municipality for the period of 2009 to 2014. The number of respondent of this research was 111 respondents. The data was obtained by direct surveys and the hypothesis was tested with multiple regressions analysis.

The result showed that board of the council's knowledge about budget influenced the control board on Regional Budget (APBD). Besides, this research also documented that interaction between leadership type with knowledge about budget and interaction between public participation with knowledge about budget influenced the control from board on the Regional Budget (APBD). On the other hand, both interaction between accountability and public policy transparency did not influence the control board of the council on Regional Budget (APBD).

Keywords : Leadership type, Accountability, Public participation, Transparency in Public Policy, Budgeting knowledge, Control board on Regional Budget (APBD).
\end{abstract}

\section{PENDAHULUAN}

Bergulirnya gelombang reformasi diiring pula dengan bergulirnya agenda desentralisasi keuangan dan otonomi daerah. Penyelenggaraan desentralisasi keuangan dan otonomi daerah diikuti dengan adanya pelimpahan wewenang dari pusat kepada daerah yang diikuti pula adanya pelimpahan dana yang bersumber dari Anggaran Pendapatan

\footnotetext{
${ }^{1}$ Staf Dosen Jurusan Manajemen Fakultas Ekonomi Dan Bisnis Universitas Cenderawasih
} 
dan Belanja Daerah (APBD). Pelimpahan dana ini diiringi dengan dilaksanakannya reformasi anggaran daerah (budgeting reform).

Pelaksanaan budgeting reform akan sukses bila ditopang dengan sarana pengawasan pengelolaan anggaran secara optimal (Freeman et al., 2003 dan Tuasikal, 2007). Pandangan Amiq (2010:10) bahwa esensi pengelolaan APBD sebagai dasar utama penyelenggaraan otonomi daerah tidak akan berhasil tanpa disertai sistem pengawasan (toezicht) yang kuat.

Fungsi pengawasan dapat dilakukan melalui optimalisasi peran DPRD sebagai salah satu institusi yang paling memiliki posisi dan peran strategis dalam pelaksanaan pengawasan APBD yang dikelola eksekutif (Syahruddin dan Taifur, 2002). Hal tersebut menjadi semakin meningkat karena hubungan antara legislatif dan eksekutif di daerah telah samasama memiliki power, yaitu bersifat sejajar dan menjadi mitra. James (1985:125) mengemukakan bahwa keuangan daerah adalah keuangan milik rakyat dan tidak ada penggunaan uang rakyat tanpa pengawasan dari rakyat. Dalam hal ini, DPRD merupakan representasi dari rakyat, oleh rakyat, dan untuk rakyat dengan fungsi utamanya adalah menjalan-kan fungsi pengawasan, selain fungsi legislasi dan fungsi anggaran.

Apabila DPRD tidak dapat berfungsi dengan baik dalam menjalankan peranannya sebagai pengawas anggaran daerah, tentunya akan membuka peluang yang besar bagi eksekutif untuk lebih leluasa melakukan penyalah-gunaan kewenangan atas penyelenggaraan pemerintahan yang diamanatkan, khususnya dalam pengelolaan APBD (Handayaningrat 1985:143; Shield et al., 1998:67; Darwis, 2008).

Pengawasan APBD dapat dilakukan dengan baik bila anggota dewan selaku pengawas mempunyai pengetahuan yang memadai tentang anggaran (Herbert et al. 1984:3; Newkirk, 1986:23; Peterson, 1994:55; Chong dan Chong, 2002; Yuen, 2007; serta Basri, 2008). Asumsinya, bagaimana mungkin seorang anggota dewan dapat memberikan jaminan bahwa pengawasan yang dilakukan telah berjalan 
dengan baik apabila anggota dewan tersebut tidak memiliki penge-tahuan yang memadai tentang keseluruhan struktur, prosedur, dan mekanisme penyusunan anggaran, tidak menguasai undang-undang dan kebijakankebijakan anggaran, terutama tidak memiliki kemampuan dalam mendeteksi terjadinya kegagalan anggaran. Yudono (2002) dan Mardiasmo (2003) menegaskan bahwa setidaknya pengetahuan yang akan dibutuhkan anggota dewan dalam melakukan fungsi pengawasan, salah satunya adalah pengetahuan tentang anggaran.

Di samping pengetahuan dewan tentang anggaran yang dapat memengaruhi pengawasan keuangan daerah (APBD), partisipasi rakyat, transparansi, dan akuntabilitas juga merupakan faktor-faktor situasional yang turut memengaruhi pengawasan APBD yang dilakukan oleh dewan (Pramono, 2002; Sopanah dan Mardiasmo, 2003). Hal yang perlu diketahui bahwa dengan adanya otonomi daerah, peran masyarakat sebagai stakeholders melalui DPRD sangat dibutuhkan dalam rangka mengawasi kinerja pemerintah (Islamy, 2003:17). Pandangan Darwis (2008) bahwa peran aktif masyarakat dalam advokasi anggaran akan menunjang pengetahuan dewan dalam menjalankan pengawasan APBD, terutama dalam hal mengontrol bahwa pelaksanaan APBD benar-benar telah sesuai dengan harapan masyarakat di lapangan.

Aspek penting partisipasi masyarakat akan tercipta bila didukung dengan transparansi kebijakan publik dalam rangka pengawasan pengelolaan anggaran. Pandangan Sulistoni (2003:35) dan Dwiyanto (2006:223) bahwa semakin transparan sebuah kebijakan publik, maka pengawasan yang dilakukan oleh dewan akan semakin meningkat karena masyarakat juga terlibat dalam mengawasi kebijakan publik tersebut. Tanpa adanya informasi tentang penganggaran yang transparan dan mudah diakses oleh publik, DPRD dan masyarakat tidak punya kesempatan untuk bisa mengetahui, menganalisis, dan memengaruhi kebijakan-kebijakan pemerintah, terutama terkait pengelolaan anggaran. 
Selain partisipasi rakyat dan transparansi anggaran, akuntabilitas telah menjadi suatu konsekuensi logis akan terciptanya fungsi pengawasan keuangan daerah (Krina, 2003). Semakin memadai pengetahuan dan penguasaan terhadap standar operasional prosedur akuntabilitas kinerja instansi pemerintah daerah, maka semakin tinggi kapabilitas dewan untuk mengetahui, menilai, dan mengontrol tingkat keberhasilan dan kegagalan pelaksanaan tugas serta tanggung jawab instansi, termasuk yang terkait dengan kinerja finansial pemerintah baik dari segi efisiensi dan efektivitas atas pengelolaan anggaran daerah.

Berdasarkan uraian tersebut di atas, peranan DPRD sangat besar dan memiliki nilai strategis dalam pengawasan APBD terutama apabila didukung dengan kualitas sumber daya manusia lembaga DPRD berupa pengetahuan anggaran yang memadai serta penyeleng-garaan prinsipprinsip good governance yang mengedepankan akun-tabilitas, partisipasi masyarakat, transparansi, dan penerapan gaya kepemimpinan yang baik. Dengan demikian, penelitian ini dilakukan dengan tujuan menguji secara empiris apakah pengetahuan dewan tentang anggaran dapat memengaruhi pengawasan APBD dan apakah gaya kepemimpinan, akuntabilitas, partisipasi masyarakat, dan transpa-ransi kebijakan publik sebagai variabel pemoderasi dapat berpengaruh terhadap hubungan antara pengetahuan dewan tentang anggaran dengan pengawasan APBD, yaitu dengan studi pada DPRD Provinsi Papua, DPRD Kabupaten Jayapura dan DPRD Kota Jayapura.

\section{LANDASAN TEORI, KERANGKA KONSEPTUAL, DAN PENGEMBA- NGAN HIPOTESIS}

\section{Pengetahuan Dewan Tentang Anggaran dan Pengawasan APBD}

Pengawasan APBD dapat dilakukan dengan baik apabila dewan mempunyai pengetahuan tentang anggaran yang memadai. Spilker (1995) mengungkapkan bahwa pengetahuan yang tinggi akan sangat menunjang kualitas hasil kerja, di samping mampu mengatasi kerumitan pekerjaan yang dihadapi seseorang. Menurut Tubbs (1992) bahwa 
dalam mendeteksi sebuah kesalahan, maka se-orang yang berada dalam profesi apapun harus didukung dengan pengetahuan yang memadai tentang apa dan bagaimana kesalahan tersebut terjadi.

Penelitian Kennedy (1993) yang menganalisis interaksi pengetahuan dengan kualitas hasil kerja dan membuktikan bahwa pengetahuan dan kemampuan memecahkan masalah yang tinggi memiliki hubungan yang positif terhadap kualitas hasil pekerjaan. Sehubungan dengan hal tersebut, Yudono (2002) menyatakan bahwa,

DPRD akan mampu menggunakan hak-haknya secara tepat, melaksanakan tugas dan kewajibannya secara efektif, serta menempatkan kedudukannya secara proporsional jika setiap anggota mempunyai pengetahuan yang memadai dalam hal konsepsi teknis penyelenggaraan pemerintahan dan kebijakan publik. Pengetahuan yang akan dibutuhkan dewan dalam melakukan pengawasan APBD salah satunya adalah pengetahuan tentang anggaran.

Berdasarkan uraian di atas, dapat dikatakan bahwa apabila semakin berkualitas pengetahuan yang dimiliki oleh para anggota, maka kinerja organisasi/lembaga juga akan menjadi semakin berkualitas. Hal ini berarti, apabila semakin baik pengetahuan yang dimiliki anggota dewan tentang anggaran, maka kinerja pengawasannya akan semakin optimal. Sebaliknya jika pengetahuan tentang anggaran lemah, maka dewan hanya pasif dan menerima rancangan usulan APBD yang diajukan oleh eksekutif tanpa berupaya menelaah dan menelusuri bah-wa anggaran yang diajukan telah sesuai dengan aspirasi masyarakat dan rencana strategi daerah, sehingga pada akhirnya tidak dapat men-deteksi terjadinya kebocoran anggaran. Oleh karena itu, hipotesisnya dirumuskan sebagai berikut:

H.1: Diduga, pengetahuan dewan tentang anggaran berpengaruh terhadap pengawasan keuangan daerah (APBD). 


\section{Gaya Kepemimpinan dan Pengawasan APBD}

Kepemimpinan yang baik merupakan syarat mutlak terwujudnya tata kelola pemerintahan yang baik. Dalam ruang lingkup pengawasan, Nawawi (1989:67) dan Fatchurrochman (2002) menegaskan bahwa,

Keterlibatan aktif pemimpin organisasi publik dalam rangka pengawasan penyelenggaraan pemerintahan sangat efektif untuk mengendalikan kegiatan aparat pemerintahan sehingga dapat terwujud suatu pemerintahan yang bersih dan berwibawa (clean and strong government).

Hal ini berarti bahwa aspek kepemimpinan memegang peranan yang sangat penting dalam menjalankan fungsi pengawasan.

Sehubungan dengan hal tersebut, Yudono (2002) menegaskan bahwa,

....DPRD akan memainkan peranannya di dalam menjalankan fungsi pengawasan dengan baik apabila pimpinan dan anggota-anggotanya berada dalam kualifikasi ideal, dalam arti memahami benar tentang hak, tugas, dan wewenangnya serta mampu mengaplikasikannya secara baik, dan didukung dengan kualitas pengetahuan dan pengalaman di bidang politik dan pemerintahan yang memadai.

Hal ini mengindikasikan bahwa peran sentral pengetahuan sebagai sumber keunggulan kompetitif, menuntut lembaga/organisasi DPRD untuk turut mendorong terciptanya suatu organisasi pembelajar (learning organization) guna peningkatan kapasitas dan kualitas pengetahuan anggota dalam rangka pencapaian kinerja organisasi yang lebih tinggi. Komitmen pimpinan organisasi/lembaga DPRD sangat dibutuhkan untuk menciptakan iklim yang kondusif bagi pembelajaran kepada para anggota, sehingga pengetahuan memadai dari para anggota dewan yang mendukung penerapan anggaran dapat tercipta, terutama dalam rangka mengoptimalkan kinerja pengawasan APBD yang diamanatkan sebagai dasar pencapaian tujuan lembaga DPRD. 
Menurut Sedarmayanti (2009:184), keberhasilan dari seorang pemimpin menjalankan kepemimpinannya untuk mencapai tujuan organisasi bergantung pada gaya kepemimpinan yang diterapkan. Carver dan Sergiovanni (1969:158) menyatakan bahwa,

.......gaya kepemimpinan yang tepat adalah gaya kepemimpinan yang tinggi orientasi tugas dan orientasi hubungan manusia.

Gaya kepemimpinan yang tinggi orientasi tugas dan hubungan adalah perilaku pemimpin yang banyak mengalokasikan waktu untuk mengadakan perubahan dan senantiasa meningkatkan kualitas pelayanan/melayani kepada para anggotanya (Lantu, 2007:29). Salah satu karakteristik gaya kepemimpinan pelayan, yaitu memberikan kesempatan pengikut untuk terus belajar (learning organization), memberikan keteladanan, dan memberdayakan anggota (Laub, 1999:43). Pandangan Senge (1990:315), pemimpin model ini senantiasa berfikir akan pentingnya kualitas pengetahuan, pengalaman, dan pembelajaran bagi anggotanya, sehingga ia akan berperan sebagai perancang (as designer), sebagai pengasuh (as steward), dan sebagai guru (as teacher) bagi anggotanya dalam organisasi.

Temuan-temuan tersebut di atas memberikan sinyal bagi penelitian ini bahwa variabel gaya kepemimpinan yang diterapkan oleh pimpinan lembaga DPRD pada setiap tingkatan organisasi terutama yang terkait pengelolaan anggaran akan menunjang pengetahuan dewan tentang anggaran secara memadai melalui learning organisasi, sekaligus akan memengaruhi efektivitas kinerja yang diemban anggota dewan dalam menjalankan fungsi pengawasan pada keseluruhan taha-pan APBD. Oleh karena itu, hipotesisnya dirumuskan sebagai berikut:

H.2: Diduga, semakin baik pengetahuan tentang anggaran dan gaya kepemimpinan, maka semakin tinggi pengawasan APBD yang dilakukan oleh anggota dewan. 


\section{Akuntabilitas dan Pengawasan APBD}

Akuntabilitas publik adalah kewajiban pihak pemegang amanah untuk memberikan pertanggungjawaban, menyajikan, melaporkan, dan mengungkapkan segala aktivitas dan kegiatan yang menjadi tanggungjawabnya kepada pihak pemberi amanah yang memiliki hak dan kewenangan untuk meminta pertanggungjawaban tersebut (Mardiasmo, 2002:20). Krina (2003) mengemukakan bahwa

.....akuntabilitas bermakna pertanggungjawaban dengan menciptakan fungsi pengawasan melalui distribusi kekuasaan pada berbagai lembaga pemerintahan sehingga mengurangi penumpukan kekuasaan, serta menciptakan kondisi saling mengawasi (checks and balances system).

Berdasarkan peranan tersebut, maka DPRD semakin dituntut untuk melakukan penguatan kapasitas SDM yang termanifestasi melalui kualitas pengetahuan, keahlian, dan penguasaan secara memadai terhadap standar operasional prosedur akuntabilitas kinerja instansi pemerintah daerah, guna pembinaan dan pengawasan (Mardiasmo, 2002:31; Pramita et al., 2010). Pandangan Agustian (2009) bahwa lemahnya penerapan akuntabilitas keuangan pemerintah disebabkan minimnya fungsi pengawasan dan terbatasnya kualitas sumber daya manusia yang terlibat pada keseluruhan pengelolaan keuangan negara.

Apabila pengetahuan dewan tentang pedoman akuntabilitas kinerja pemerintah minimal, akan membuat DPRD hanya pasif dan menerima laporan akuntabilitas kinerja yang diajukan oleh pemerintah daerah tanpa berupaya untuk menelaah dan menelusuri seberapa jauh pencapaian kinerja yang telah dihasilkan pemerintah daerah, serta seberapa efektif dan efisien penggunaan dan penyerapan anggaran untuk kepentingan publik sehingga pada akhirnya tidak mampu mendeteksi dan mengetahui terjadinya pemborosan anggaran.

Dengan demikian, asumsi yang dapat dirumuskan bahwa semakin tinggi penyelenggaraan akuntabilitas atas pengelolaan APBD di daerah, maka hal tersebut akan diikuti pula dengan tuntutan peningkatan 
pengetahuan dewan terkait aktivitas penganggaran, sehingga pada akhirnya kualitas kinerja pengawasan anggaran yang dilakukan DPRD akan menjadi semakin meningkat. Oleh karena itu, hipotesisnya dapat dirumuskan:

\section{H.3: Diduga, semakin baik pengetahuan tentang anggaran dan akun- tabilitas publik, maka semakin tinggi pengawasan APBD yang dilakukan oleh anggota dewan.}

\section{Partisipasi Masyarakat dan Pengawasan APBD}

Terciptanya akuntabilitas kepada publik akan sangat dipengaruhi oleh partisipasi warga masyarakat dalam penyusunan dan pengawasan anggaran (Rubin, 1996). Sejalan dengan hal tersebut, Isharyanto (2007) mengemukakan bahwa adanya perubahan paradigma anggaran di era reformasi menuntut adanya partisipasi rakyat dalam keseluruhan siklus anggaran. Asumsinya bahwa dengan terselenggaranya partisipasi rakyat yang dilakukan oleh panitia dan tim anggaran dalam siklus anggaran akan memperkuat pengawasan dalam proses penyusunan dan pelaksanaan anggaran (Sirajuddin, 2006). Pelaksanaan partisipasi masyarakat dapat dilakukan oleh anggota dewan melalui penjaringan aspirasi masyarakat atau yang dikenal dengan kegiatan musrembang.

Melalui kegiatan musrembang, masyarakat berhak untuk memengaruhi DPRD dalam pelaksanaan APBD sebagai dokumen publik (Puriyadi, 2007). Masyarakat memengaruhi DPRD dengan memberikan informasi-informasi yang dapat menunjang pengetahuan DPRD dalam melakukan pengawasan APBD. Informasi tersebut dapat berupa usulan dan kritik dari masyarakat mengenai sejauh mana penyelenggaraan APBD telah dicapai sehingga dasar dalam penyusunan APBD yang menuntut bahwa APBD harus sesuai dengan aspirasi masyarakat dapat terpenuhi secara nyata. Pandangan Darwis (2008) bahwa peran aktif masyarakat dalam advokasi anggaran akan menunjang pengetahuan dewan dalam menjalankan pengawasan APBD, terutama dalam hal mengontrol bahwa pelaksanaan APBD benar-benar telah sesuai dengan 
harapan masyarakat di lapangan. Dengan demikian, maka hipotesis keempat dirumuskan sebagai berikut:

\section{H.4: Diduga, semakin baik pengetahuan tentang anggaran dan partisipasi masyarakat, maka semakin tinggi pengawasan APBD yang dilakukan oleh anggota dewan.}

\section{Transparansi Kebijakan Publik dan Pengawasan APBD}

Transparansi merupakan prasyarat untuk terciptanya partisipasi masyarakat yang semakin sehat (Sulistoni, 2003:35), di samping prinsip transparansi juga merupakan saluran terciptanya akuntabilitas kepada publik (Mardiasmo, 2002: 20). Transparansi kebijakan publik dibangun atas pijakan kebebasan arus informasi yang memadai, disediakan untuk dipahami, serta (untuk kemudian) dapat dipantau guna pengambilan keputusan ekonomi, sosial, dan politik oleh pihak-pihak yang membutuhkan informasi atas aktivitas pengelolaan sumber daya publik (Mardiasmo, 2002:18; Sopanah dan Mardiasmo, 2003).

Anggaran yang disusun oleh pihak eksekutif dikatakan transparan jika memenuhi beberapa kriteria berikut: (1) Terdapat pengumuman kebijakan anggaran, (2) Tersedia dokumen anggaran dan mudah diakses, (3) Tersedia laporan pertanggungjawaban yang tepat waktu, (4) Terakomodasinya suara/usulan dari masyarakat, dan (5) Terdapat sistem pemberian informasi kepada publik (Mardiasmo, 2003). Pandangan Sulistoni (2003:35) bahwa,

....semakin transparan sebuah kebijakan publik, maka pengawasan yang dilakukan anggota dewan akan semakin meningkat karena masyarakat terlibat dalam mengawasi kebijakan publik tersebut. Tanpa adanya informasi yang memadai tentang penganggaran, DPRD dan masyarakat tidak punya kesempatan mengetahui, menganalisis, dan memengaruhi kebijakan-kebijakan pemerintah.

Hal tersebut di atas mengindikasikan bahwa semakin transparan kebijakan publik di dalam penyelenggaraan APBD, maka semakin mudah bagi masyarakat dalam mengakses dan memonitor segala informasiinformasi yang terkait dengan pengelolaan dan implementasi APBD. 
Hal ini berarti, bila semakin tinggi penyelenggaraan transparansi kebijakan publik di daerah, maka semakin menunjang pengetahuan dewan dalam mendeteksi terjadinya kebocoran anggaran, sehingga pada akhirnya pelaksanaan fungsi pengawasan APBD oleh DPRD akan menjadi semakin optimal. Oleh karenanya, hipotesis kelima dapat dirumuskan sebagai berikut:

H.5: Diduga, semakin baik pengetahuan tentang anggaran dan transparansi, maka semakin tinggi pengawasan APBD yang dilakukan oleh anggota dewan.

Berdasarkan hal tersebut di atas, maka disusun kerangka proses berfikir sebagai berikut:

Gambar 1. Kerangka Konseptual

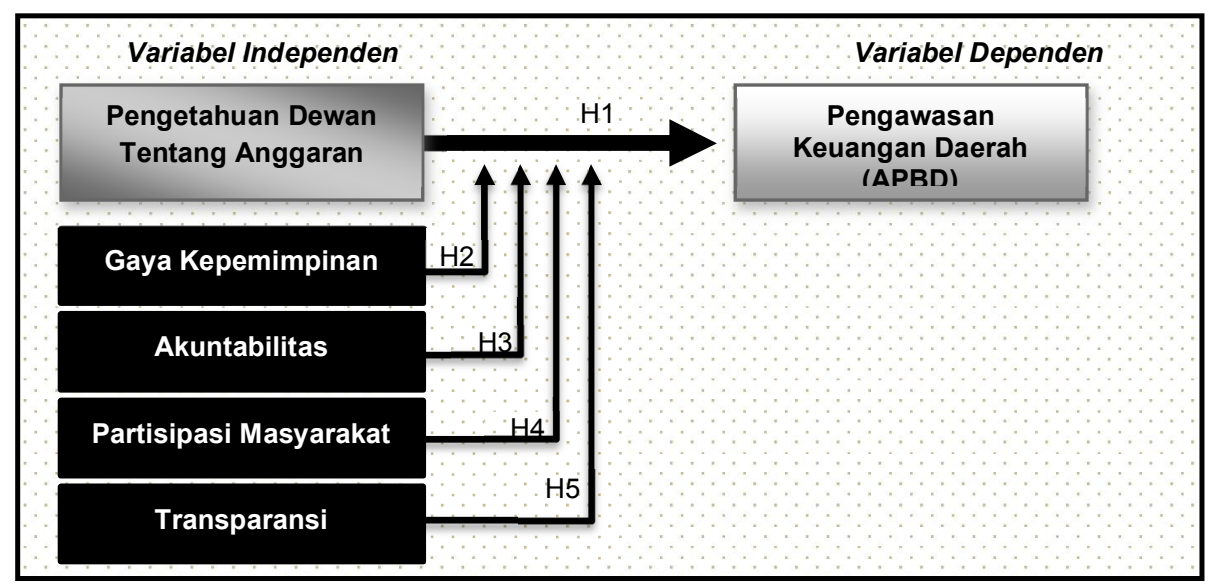

Sumber, Data diolah Tahun 2013

\section{METODE PENELITIAN}

\section{Pendekatan dan Jenis Penelitian}

Jenis penelitian yang digunakan adalah eksplanatori dengan pendekatan kuantitatif, serta metode yang digunakan adalah metode penelitian survei.

\section{Populasi dan Sampel Penelitian}

Populasi dalam penelitian ini adalah seluruh anggota dewan pada kantor DPRD Provinsi Papua, DPRD Kabupaten, dan DPRD Kota 
Jayapura. Untuk responden anggota dewan, semua populasi dijadikan sebagai sampel.

\section{Teknik Pengumpulan Data}

Pengumpulan data dalam penelitian ini, yaitu menggunakan survei langsung dan instrumen yang digunakan adalah kuesioner (angket).

\section{Definisi Operasional dan Pengukuran Variabel}

Penelitian ini menguji 6 variabel, terdiri dari 1 variabel depen-den, 1 variabel independen dan 4 variabel moderasi. Semua variabel dalam penelitian ini diukur berdasarkan teknik skala likert 5 angka (skor). slSkor 5 (SS= Sangat Setuju), 4 ( $\mathrm{S}=$ Setuju, 3 (RR= Ragu-Ragu), 2 (TS=Tidak Setuju), dan 1 (STS=Sangat Tidak Setuju).

\section{Variabel dependen: Pengawasan Keuangan Daerah (APBD)}

Pengawasan APBD adalah kegiatan pengawasan yang dilakukan oleh DPRD secara intensif pada saat perencanaan, pelaksanaan, dan per-tanggungjawaban APBD. Indikator-indikator yang digunakan untuk mengukur variabel pengawasan keuangan daerah (APBD) mengacu pada instrumen yang diadopsi dari penelitian Sopanah dan Mardiasmo (2003) yang terdiri dari 12 butir pertanyaan. Variabel pengawasan APBD didasarkan pada item-item pertanyaan tentang pengawasan yang dilakukan oleh anggota DPRD pada keseluruhan tahap APBD, yaitu tahap perencanaan, pelaksanaan, dan pertanggungjawaban APBD.

\section{Variabel Independen: Pengetahuan Dewan Tentang Anggaran}

Pengetahuan dewan tentang angaran adalah pengetahuan anggota dewan dalam hal menyusun anggaran (RAPBD/APBD), deteksi serta identifikasi terhadap pemborosan dan kebocoran anggaran. Indikator-indikator yang digunakan untuk mengukur variabel pengetahuan tentang anggaran mengacu pada instrumen yang diadopsi dari penelitian Sopanah dan Mardiasmo (2003) yang terdiri dari 4 butir 
pertanyaan. Variabel pengetahuan tentang anggaran didasarkan pada item-item pertanyaan tentang pengetahuan dewan terhadap penyusunan dan pelaksanaan APBD, pengetahuan pada saat melakukan pengawasan guna mengantisipasi terjadinya kebocoran dan pemborosan dalam pelaksanaan APBD, pengetahuan terhadap teknis atau alur penyusunan APBD.

\section{Variabel Moderasi: Gaya Kepemimpinan}

Gaya kepemimpinan adalah strategi yang digunakan oleh para pimpinan pada setiap tingkatan lembaga sebagai proses memengaruhi anggo-tanya dalam rangka pencapaian tujuan organisasi yang telah ditetapkan, terutama dalam memperkuat fungsi kontrol atau pengawasan APBD. Indikator-indikator yang digunakan untuk mengukur variabel gaya kepemimpinan mengacu pada kuesioner penelitian oleh Engko dan Gudono (2007) yang terdiri dari 14 butir pertanyaan, kemudian peneliti kembangkan sesuai situasi dan teori terkait. Variabel gaya kepemimpinan didasarkan pada item-item pertanyaan tentang penerapan gaya kepemimpinan yang berorientasi tugas dan gaya kepemimpinan yang berorientasi hubungan.

\section{Variabel Moderasi: Akuntabilitas}

Akuntabilitas adalah kewajiban bagi pihak pemegang amanah (dewan/ agent) untuk memberikan pertanggungjawaban, menyajikan, melapor-kan, dan mengungkapkan segala aktivitas dan kegiatan yang menjadi tanggungjawabnya kepada pihak pemberi amanah (rakyat/prinsipal) yang memiliki hak dan kewenangan untuk meminta pertanggung-jawaban tersebut. Indikator-indikator yang digunakan untuk mengukur variabel akuntabilitas mengacu pada instrumen yang diadopsi dari penelitian Pramita dan Andriyani (2010) yang terdiri dari 7 butir pertanyaan. Variabel akuntabilitas didasarkan pada item-item pertanyaan tentang pengetahuan dewan mengenai standar operasional prosedur akuntabilitas, pengetahuan dewan tentang prinsip penyusunan LAKIP 
(laporan harus disusun secara jujur, objektif, dan transparan), dan pengetahuan dewan tentang mekanisme penyampaian LAKIP sebagai media untuk mengetahui dan menilai keberhasilan dan kegagalan dalam melaksanakan tugas dan tanggung jawab instansi.

\section{Variabel Moderasi: Partisipasi Masyarakat}

Partisipasi masyarakat adalah keterlibatan masyarakat dalam setiap aktivitas proses penganggaran yang dilakukan oleh dewan pada saat penyusunan arah dan kebijakan, penentuan strategi dan prioritas serta advokasi anggaran. Indikator-indikator yang digunakan untuk mengukur variabel partisipasi masyarakat mengacu pada instrumen yang diadopsi dari penelitian Sopanah dan Mardiasmo (2003) yang terdiri dari 7 butir pertanyaan. Variabel partisipasi masyarakat didasarkan kepada item-item pertanyaan tentang penjaringan aspirasi masyarakat secara aktif, pasif, dan reaktif.

\section{Variabel Moderasi: Transparansi Kebijakan Publik}

Transparansi kebijakan publik adalah adanya keterbukaan tentang ang-garan yang mudah diakses oleh masyarakat. Indikatorindikator yang digunakan untuk mengukur variabel partisipasi masyarakat mengacu pada instrumen yang diadopsi dari penelitian Sopanah dan Mardiasmo (2003) yang terdiri dari 5 butir pertanyaan. Variabel transparansi kebi-jakan publik didasarkan pada item-item pertanyaan tentang terdapatnya pengumuman tentang kebijakan anggaran, tersedianya dokumen ang-garan yang mudah diakses, tersedianya laporan pertanggungjawaban yang tepat waktu, terakomodasinya suara/usulan rakyat, dan terdapat sistem pemberian informasi kepada publik.

\section{Teknik Analisis Data}

Sesuai dengan rumusan hipotesis $\mathrm{H}_{1}$ sampai dengan $\mathrm{H}_{5}$, maka pengujian hipotesis dilakukan dengan menggunakan alat analisis regresi 
linier berganda. Sehubungan dengan hal tersebut maka persamaan regresi untuk menguji hipotesis adalah sebagai berikut:

$$
\begin{aligned}
Y= & \alpha+\beta_{1} \cdot X_{1}+\beta_{2} \cdot X_{2}+\beta_{3} \cdot X_{3}+\beta_{4} \cdot X_{4}+\beta_{5} \cdot X_{5}+\beta_{6} \cdot X_{1} \cdot X_{2}+\beta_{7} \cdot X_{1} \cdot X_{3}+ \\
& \beta_{8} \cdot X_{1} \cdot X_{4}+\beta_{9} \cdot X_{1} \cdot X_{5}+\varepsilon
\end{aligned}
$$

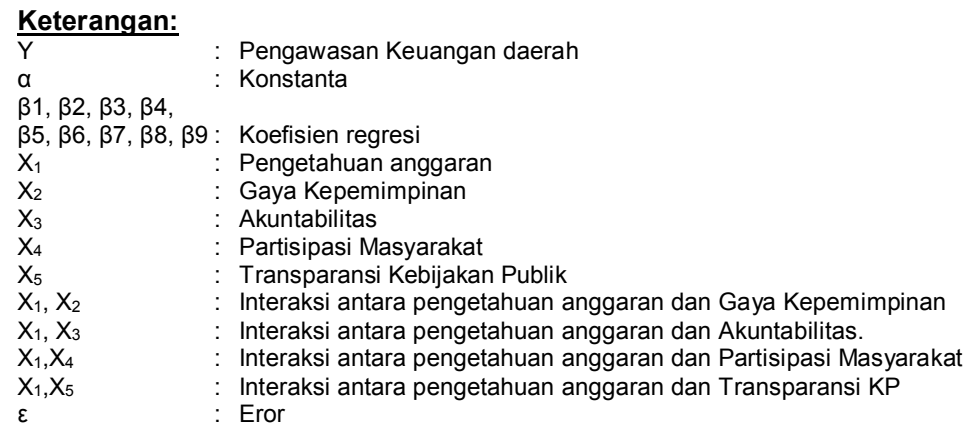

\section{HASIL ANALISIS DAN PEMBAHASAN}

\section{Demografi Responden}

Data demografi berikut menyajikan beberapa informasi umum mengenai karakteristik responden yang digunakan dalam penelitian ini berdasarkan jenis kelamin, usia, jenjang pendidikan, dan latar belakang pendidikan.

Tabel 1

\begin{tabular}{|c|c|c|c|c|c|c|c|}
\hline \multicolumn{2}{|c|}{ Kelompok } & Frekuensi & $\%$ & \multicolumn{2}{|c|}{ Kelompok } & Frekuensi & $\%$ \\
\hline $\begin{array}{l}\text { Jenis } \\
\text { Kelamin }\end{array}$ & $\begin{array}{l}\text { Pria } \\
\text { Wanita }\end{array}$ & $\begin{array}{r}76 \text { Orang } \\
9 \text { Orang }\end{array}$ & $\begin{array}{l}89,4 \% \\
10,6 \% \\
100 \%\end{array}$ & Usia & $\begin{array}{l}31-40 \text { Tahun } \\
41-50 \text { Tahun } \\
>50 \text { Tahun }\end{array}$ & $\begin{array}{l}15 \text { Orang } \\
53 \text { Orang } \\
17 \text { Orang }\end{array}$ & $\begin{array}{l}17,6 \% \\
62,4 \% \\
20,0 \% \\
100 \% \\
\end{array}$ \\
\hline $\begin{array}{l}\text { Jenjang } \\
\text { Pendidikan }\end{array}$ & $\begin{array}{l}\text { Strata } 2 \text { (S2) } \\
\text { Strata } 1 \text { (S1) } \\
\text { Diploma } \\
\text { SMU }\end{array}$ & $\begin{array}{r}15 \text { Orang } \\
43 \text { Orang } \\
3 \text { Orang } \\
24 \text { Orang }\end{array}$ & $\begin{array}{c}17,6 \% \\
50,6 \% \\
3,5 \% \\
\underline{28,2 \%} \\
100 \%\end{array}$ & $\begin{array}{l}\text { Latar } \\
\text { Belakang } \\
\text { Pendidikan }\end{array}$ & $\begin{array}{l}\text { Ilmu sosial dan } \\
\text { politik } \\
\text { Teknik } \\
\text { Ilmu agama } \\
\text { Akuntansi } \\
\text { Manajemen } \\
\text { Hukum } \\
\text { Lainnya } \\
\end{array}$ & $\begin{array}{l}6 \text { Orang } \\
5 \text { Orang } \\
5 \text { Orang } \\
0 \text { Orang } \\
21 \text { Orang } \\
19 \text { Orang } \\
29 \text { Orang }\end{array}$ & \begin{tabular}{r|}
$7,1 \%$ \\
$5,9 \%$ \\
$5,9 \%$ \\
$0,0 \%$ \\
$24,7 \%$ \\
$22,4 \%$ \\
$34,1 \%$ \\
$100 \%$ \\
\end{tabular} \\
\hline $\begin{array}{l}\text { Tingkat Pen } \\
\text { - Kuesioner } \\
\text { - Kuesioner } \\
\text { - Kuesioner }\end{array}$ & $\begin{array}{l}\text { mbalian Kue } \\
\text { ang didistribus } \\
\text { ang tidak dike } \\
\text { ang kembali }\end{array}$ & $\begin{array}{l}\text { er: } \\
\text { alikan }\end{array}$ & $\begin{array}{l}=111 \\
=23 \\
=88\end{array}$ & $\begin{array}{l}\text { - Kuesioner y } \\
\text { - Kuesioner y } \\
\text { - Respon rate }\end{array}$ & $\begin{array}{l}\text { g tidak memenu } \\
\mathrm{g} \text { diolah }\end{array}$ & & $\begin{array}{l}3 \\
85 \\
79,28 \% \\
\end{array}$ \\
\hline
\end{tabular}

Karaktersistik Responden dan Tingkat Respon Rate

Sumber: Sekretariat DPRD dan data diolah, Tahun 2012

Tabel di atas menunjukkan bahwa dari 85 responden yang telah memenuhi kriteria untuk diolah, terdapat 76 orang diantaranya pria dan 9 
orang di antaranya wanita dengan usia responden yang paling banyak berpartisipasi, yaitu antara 41 sampai 50 tahun dan rata-rata responden berjenjang pendidikan strata 1 .

\section{Hasil Uji Instrumen Penelitian}

\section{Hasil Uji Validitas.}

Hasil pengujian instrumen penelitian ini dapat diuraikan sebagai berikut:

Tabel 2

Hasil Uji Confirmatory Factor Analysis

\begin{tabular}{|l|c|c|c|c|c|c|}
\hline \multirow{2}{*}{ Variabel } & \multicolumn{3}{|c|}{ KMO \& BARLET TEST } & \multicolumn{2}{c|}{ Total Variance Explained } & $\begin{array}{c}\text { Rotate } \\
\text { Component } \\
\text { Matrix }\end{array}$ \\
\cline { 2 - 7 } & KMO & $\begin{array}{c}\text { BTS } \\
\text { Chi- } \\
\text { square }\end{array}$ & Sig. & Component & $\begin{array}{c}\text { Elgenvalue } \\
\text { Loading } \\
\text { Total } \\
\text { Component }\end{array}$ \\
\hline Pengetahuan & 0,623 & 187,638 & 0,000 & 4 & $65,655 \%$ & 1 \\
\hline Kepemimpinan & 0,706 & 609,869 & 0,000 & 14 & $69,949 \%$ & 4 \\
\hline Akuntabilitas & 0,796 & 304,040 & 0,000 & 7 & $73,112 \%$ & 2 \\
\hline Partisipasi & 0,675 & 209,299 & 0,000 & 7 & $65,083 \%$ & 2 \\
\hline Transparansi & 0,618 & 115,827 & 0,000 & 5 & $73,309 \%$ & 2 \\
\hline Pengawasan & 0,781 & 374,386 & 0,000 & 12 & $62,188 \%$ & 3 \\
\hline
\end{tabular}

Sumber: Data primer diolah Tahun 2012

Berdasarkan hasil uji CFA di atas, nilai Kaiser-Meyer-Oklin of Sampling Adequacy (KMO-MSA) terhadap variabel pengetahuan anggaran (4 item), gaya kepemimpinan (14 item), akuntabilitas (7 item), partisipasi masyarakat (7 item), transparansi (5 item), dan variabel pengawasan (12 item), menunjukkan bahwa semua item memiliki loading factor di atas 0,50 atau tidak ada yang dikeluarkan. Di samping itu, nilai Bartlett's test of Sphericity dengan Chi-squares signifikan pada 0,000, maka dapat disimpulkan bahwa uji analisis faktor dapat dilanjutkan. Kemudian berdasarkan analisis faktor untuk masing-masing variabel, dapat diketahui bahwa dari rotase komponen matriks analisis faktor menunjukkan bahwa tiap-tiap konstruk memiliki undimensionalitas atau dengan kata lain semua indikator yang digunakan memiliki faktor penjelas yang kuat, sehingga dapat disimpulkan bahwa masing-masing skor butir pertanyaan adalah valid. Adapun hasil pengujian reliabilitas dapat dilihat pada Tabel berikut: 
Tabel 3

Hasil Uji Reliabilitas

\begin{tabular}{|l|c|c|}
\multicolumn{1}{|c|}{ Variabel } & Cronbach Alpha & Keterangan \\
\hline Pengetahuan & 0,824 & Reliabel \\
\hline Kepemimpinan & 0,806 & Reliabel \\
\hline Akuntabilitas & 0,857 & Reliabel \\
\hline Partisipasi & 0,796 & Reliabel \\
\hline Transparansi & 0,653 & Reliabel \\
\hline Pengawasan & 0,786 & Reliabel \\
\hline
\end{tabular}

Sumber: Data primer diolah Tahun 2012

Berdasarkan tabel di atas, hasil uji reliabilitas variabel atas 6 instrumen variabel penelitian menunjukkan Cronbach Alpha $(\alpha)$ di atas 0,60. Berdasarkan hasil uji validitas dan reliabilitas tersebut di atas, variabel-variabel yang akan diuji telah akurat dan konsisten, sehingga memenuhi syarat untuk dapat digunakan dalam analisis data.

\section{Pengujian Asumsi Klasik}

\section{Uji Normalitas}

Hasil uji normalitas melalui uji Kolmogorov-Smirnov dapat dilihat pada Tabel berikut:

Tabel 4

Rekapitulasi Hasil Uji Normalitas

\begin{tabular}{|c|c|c|}
\hline Statistik Uji & Nilai & \multirow{2}{*}{ Keterangan } \\
\cline { 1 - 2 } Kolmogorov-Smirnov Z & 0,730 & Normal \\
\hline signifikansi & 0,661 & \\
\hline
\end{tabular}

Sumber: Data primer diolah Tahun 2012

Hasil uji Kolmogorov-Smirnov pada tabel di atas menunjukkan nilai signifikansi di atas 0,05. Dengan demikian, dapat disimpulkan bahwa data terdistribusi normal.

\section{Uji Multikolinieritas}

Hasil uji multikolinearitas dapat dilihat pada Tabel berikut: 
Tabel 5

Hasil Uji Multikolinearitas

\begin{tabular}{|l|c|c|c|}
\hline \multirow{2}{*}{ Variabel } & \multicolumn{2}{c|}{ Collinearity Statistics } & \multirow{2}{*}{ Keterangan } \\
\cline { 2 - 3 } & Tolerance & VIF & \\
\hline Pengetahuan & 0,503 & 1,990 & Non Multikolinearitas \\
\hline Kepemimpinan & 0,482 & 2,075 & Non Multikolinearitas \\
\hline Akuntabilitas & 0,825 & 1,213 & Non Multikolinearitas \\
\hline Partisipasi & 0,469 & 2,131 & Non Multikolinearitas \\
\hline Transparansi & 0,749 & 1,336 & Non Multikolinearitas \\
\hline
\end{tabular}

Sumber: Hasil Pengolahan Data Tahun 2012

Berdasarkan tabel di atas, terlihat bahwa tidak ada variabel independen yang memiliki nilai tolerance $<0,10$. Di samping itu, hasil perhitungan Variance Inflation Factor (VIF) menunjukkan bahwa kelima variabel independen memiliki nilai VIF $>10$, sehingga dapat disimpulkan bahwa tidak ada multikolinearitas antara variabel independen dalam model regresi.

\section{Uji Heterokedastisitas}

Gambar 2

Scatterplot

Scatterplot

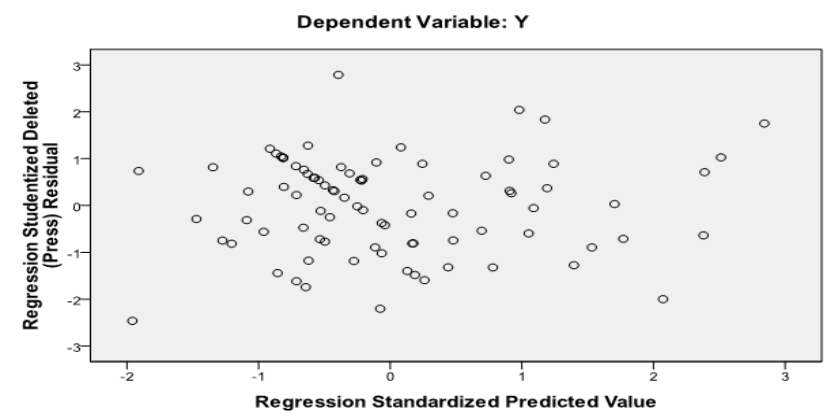

Berdasarkan gambar Scatterplot di atas, grafik menunjukkan bahwa titiktitik menyebar secara acak dan tersebar baik di atas maupun di bawah angka 0 pada sumbu $\mathrm{Y}$. Hal tersebut mengindikasikan tidak terjadi heteroskedastisitas pada model regresi, sehingga model regresi layak dipakai untuk memprediksi model. 


\section{Pembuktian Hipotesis}

Hasil regresi diuji secara statistik menggunakan analisis regresi berganda untuk mengetahui signifikansi koefisien regresi dari masingmasing variabel independen untuk menjawab hipotesis yang diajukan ( $\rho$ value). Tingkat keyakinan (confident interval) yang digunakan, yaitu sebesar 95\% (tingkat kesalahan $\alpha=5 \%$ ), sehingga jika hasil penelitian menunjukkan taraf signifikansi ( $\rho$-value) lebih kecil dari $\alpha=5 \%$ ( $\rho$-value $<$ $0,05)$, maka dapat disimpulkan bahwa variabel independen berpengaruh terhadap variabel dependen. Pembahasan hasil penelitian dapat disajikan dalam Tabel berikut:

\section{Tabel 6}

\section{Rekapitulasi Hasil Analisis Regresi Linier Berganda}

\begin{tabular}{|c|c|c|c|c|c|}
\hline $\begin{array}{l}\text { Variabel } \\
\text { Dependen }\end{array}$ & $\begin{array}{c}\text { Variabel } \\
\text { Independen }\end{array}$ & $\begin{array}{l}\text { Hipo } \\
\text { tesis }\end{array}$ & $\begin{array}{l}\text { Koefisien } \\
\text { Regresi }\end{array}$ & $\begin{array}{c}\mathrm{T} \\
\text { Hitung }\end{array}$ & $\begin{array}{l}\rho \text {-value } \\
\text { (Sig.) }\end{array}$ \\
\hline \multirow{5}{*}{$\begin{array}{c}\text { Pengawasan } \\
(\mathrm{Y})\end{array}$} & Pengetahuan $\left(\mathrm{X}_{1}\right)$ & $\mathrm{H}_{1}$ & 0,740 & 5,356 & $0,000^{\star *}$ \\
\hline & Interaksi $\mathrm{X}_{1} \mathrm{X}_{2}$ & $\mathrm{H}_{2}$ & 1,056 & 4,267 & $0,000^{* *}$ \\
\hline & Interaksi $\mathrm{X}_{1} \mathrm{X}_{3}$ & $\mathrm{H}_{3}$ & 0,359 & 1,616 & 0,110 \\
\hline & Interaksi $\mathrm{X}_{1} \mathrm{X}_{4}$ & $\mathrm{H}_{4}$ & 0,421 & 2,012 & $0,048^{*}$ \\
\hline & Interaksi $\mathrm{X}_{1} \mathrm{X}_{5}$ & $\mathrm{H}_{5}$ & $-0,245$ & $-0,994$ & 0,324 \\
\hline \multicolumn{6}{|c|}{ Constant $=6,845$} \\
\hline \multicolumn{6}{|c|}{$\begin{array}{lll}\text { ** } & \text { Signifikan pada tingkat } & 1 \% \\
\text { * } & \text { Signifikan pada tingkat } & 5 \%\end{array}$} \\
\hline \multicolumn{6}{|c|}{$\begin{array}{l}\text { Persamaan Reresi: } \\
Y=6,845+0,740 X_{1}+0,268 X_{2}+0,245 X_{3}+0,250 X_{4}-0,078 X_{5}+1,056\left(X_{1}{ }^{*} X_{2}\right)+0,359\left(X_{1}{ }^{*} X_{3}\right) \\
+0,421\left(X_{1}{ }^{*} X_{4}\right)-0,245\left(X_{1}{ }^{*} X_{5}\right)+\varepsilon\end{array}$} \\
\hline \multicolumn{6}{|c|}{$\begin{array}{ll}\text { Keterangan: } \\
\mathrm{X}_{1} & \text { diukur berdasarkan pengetahuan menyusun RAPBD/APBD; identifikasi kegagalan APBD. } \\
\mathrm{X}_{2} & \text { diukur berdasarkan gaya kepemimpinan orientasi tugas dan orientasi hubungan manusia. } \\
\mathrm{X}_{3} & \text { diukur berdasarkan pengetahuan mekanisme dan prinsip penyusunan LAKIP. } \\
\mathrm{X}_{4} & \text { diukur berdasarkan penjaringan aspirasi masyarakat secara aktif, pasif, dan reaktif. } \\
\mathrm{X}_{5} & \text { diukur berdasarkan ketersediaan informasi anggaran yang mudah diakses masyarakat. }\end{array}$} \\
\hline
\end{tabular}

Berdasarkan Tabel 6 di atas, terlihat hasil analisis regresi terhadap hipotesis pertama $\left(\mathrm{H}_{1}\right)$ yang menunjukkan bahwa variabel pengetahuan tentang anggaran $\left(X_{1}\right)$ berpengaruh terhadap variabel pengawasan APBD $(Y)$. Pengaruh tersebut ditunjukkan oleh nilai thitung dari $\left(X_{1}\right)$, yaitu sebesar 5,356 dengan taraf signifikansinya sebesar 0,000 . Oleh karena itu, ber-dasarkan taraf signifikansi $(\alpha)=5 \%, \rho$-value 0.000 lebih kecil dari $(\alpha)=5 \%(0.000<0.05)$ sehingga disimpulkan bahwa hipotesis pertama $\left(\mathrm{H}_{1}\right)$ dapat diterima. Di samping itu, hubungan yang 
ditunjukkan oleh koefisien regresi adalah positif 0,740 yang berarti bahwa setiap kenaikan satu satuan pengetahuan anggaran $\left(X_{1}\right)$, maka pengawasan $(Y)$ akan meningkat sebesar 0,740 satuan dengan menganggap variabel bebas yang lain konstan.

Hasil analisis regresi terhadap hipotesis kedua $\left(\mathrm{H}_{2}\right)$ menunjukkan bahwa variabel interaksi pengetahuan anggaran dengan gaya kepemimpinan $\left(\mathrm{X}_{1} \mathrm{X}_{2}\right)$ berpengaruh terhadap pengawasan APBD $(\mathrm{Y})$. Pengaruh tersebut ditunjukkan oleh nilai thitung sebesar 4,267 dan taraf signifikansinya sebesar 0.000 . Oleh karena itu, jika digunakan tingkat signifikansi $(\alpha)=5 \%, \rho$-value 0.000 lebih kecil dari $(\alpha)=5 \%(0.000<0.05)$ sehingga dapat disimpulkan bahwa hipotesis kedua $\left(\mathrm{H}_{2}\right)$ diterima. Di samping itu, hubungan yang ditunjukkan oleh koefisien regresi dari interaksi antara $X_{1}$ dengan $X_{2}\left(X_{1} X_{2}\right)$ adalah positif 1,056 yang berarti bahwa setiap kenaikan satu satuan dari variabel $\left(X_{1} X_{2}\right)$, maka pengawasan $(Y)$ akan meningkat sebesar 1,056 satuan dengan menganggap variabel bebas yang lain konstan.

Hasil analisis regresi terhadap hipotesis ketiga $\left(\mathrm{H}_{3}\right)$ menunjukkan bahwa variabel interaksi pengetahuan anggaran dengan akuntabilitas publik $\left(X_{1} X_{3}\right)$ tidak berpengaruh terhadap variabel pengawasan APBD $(Y)$. Hal tersebut ditunjukkan oleh koefisien regresi dari variable $\left(X_{1} X_{3}\right)$ sebesar 0,359 , nilai $t_{\text {nitung }} 1,616$ dengan tingkat signifikansinya sebesar 0,110 . Apabila berdasarkan pada taraf signifikansi $(\alpha)=5 \%, \rho$-value 0,110 lebih besar dari $(\alpha)=5 \%(0,110>0,05)$ sehingga dapat disimpulkan bahwa hipotesis ketiga $\left(\mathrm{H}_{3}\right)$ tidak dapat diterima (hipotesis ditolak).

Hasil analisis regresi terhadap hipotesis keempat $\left(\mathrm{H}_{4}\right)$ menunjukkan bahwa variabel interaksi pengetahuan anggaran dengan partisipasi masyarakat $\left(X_{1} X_{4}\right)$ berpengaruh terhadap variabel pengawasan APBD (Y). Pengaruh tersebut ditunjukkan oleh nilai $t_{\text {hitung }}$ sebesar 2,012 dengan taraf signifikansinya sebesar 0,048 . Oleh karena itu, berdasarkan tingkat signifikansi $(\alpha)=5 \%, \rho$-value 0,048 lebih kecil dari $(\alpha)=5 \%(0,048<0.05)$ sehingga dapat disimpulkan bahwa hipotesis keempat $\left(\mathrm{H}_{4}\right)$, dapat 
diterima. Di samping itu, hubungan yang ditunjukan oleh koefisien regresi dari interaksi antara $X_{1}$ dengan $X_{4}\left(X_{1} X_{4}\right)$ adalah positif 0,421 yang berarti bahwa setiap kenaikan satu satuan dari variabel $\left(X_{1} X_{4}\right)$, maka pengawasan $(Y)$ akan meningkat sebesar 0,421 satuan dengan menganggap variabel bebas yang lain konstan.

Hasil regresi terhadap hipotesis kelima $\left(\mathrm{H}_{5}\right)$ menunjukkan bahwa variabel interaksi pengetahuan anggaran dengan transparansi $\left(X_{1} X_{5}\right)$ tidak berpengaruh terhadap variabel pengawasan APBD ( $Y$ ). Hal ini ditunjukkan dengan melihat nilai koefisien regresi dari variable $\left(X_{1} X_{5}\right)$, yaitu sebesar $-0,245$, nilai $t_{\text {hitung }}$ sebesar $-0,994$ dengan taraf signifikansinya sebesar 0,324 . Apabila tingkat signifikansi $(\alpha)=5 \%, \rho$-value 0,324 lebih besar dari $(\alpha)=5 \%(0,324>0,05)$ sehingga dapat disimpulkan bahwa hipotesis kelima $\left(\mathrm{H}_{5}\right)$ tidak dapat diterima (hipotesis ditolak).

\section{Pembahasan}

\section{Pengaruh Pengetahuan Dewan tentang Anggaran terhadap Pengawasan Keuangan Daerah (APBD)}

Hasil penelitian ini membuktikan bahwa pengetahuan dewan tentang anggaran berpengaruh terhadap pengawasan APBD. Artinya, semakin tinggi pengetahuan dewan tentang anggaran, maka semakin meningkat pengawasan APBD yang dilakukan oleh anggota DPRD. Pengetahuan dewan yang dimaksud adalah meliputi pengetahuan tentang penyusunan APBD, pengetahuan tentang pelaksanaan APBD, pengetahuan tentang identifikasi kebocoran, pemborosan/ kegagalan pelaksanaan $A P B D$, pengetahuan tentang teknis atau alur penyusunan APBD, serta pengetahuan tentang tahapan pengawasan yang dimulai dari penyusunan, pelaksanaan, pelaporan dan evaluasi anggaran (APBD).

Hasil penelitian ini konsisten dengan hasil penelitian yang dilakukan oleh Indradi (2001); Syamsiar (2001); dan Sutarnoto (2002) yang menemukan bahwa kualitas anggota dewan yang diukur berdasarkan 
tingkat pendidikan, pengetahuan, pengalaman, dan keahlian berpengaruh terhadap kinerja anggota dewan yang salah satunya adalah kinerja pengawasan APBD. Hasil penelitian ini juga mendukung hasil penelitian Sopanah dan Mardiasmo (2003); Werimon et al. (2007); dan Coryanata (2007) yang menyimpulkan bahwa pengetahuan anggota dewan tentang anggaran yang merupakan salah satu unsur dari kualitas SDM berpengaruh terhadap pengawasan APBD. Temuan ini juga mendukung teori-teori yang menyatakan bahwa pengetahuan yang tinggi akan sangat menunjang kualitas dari hasil pekerjaan (Tubbs, 1992; Kennedy, 1993; Spilker, 1995; Cloyd, 1997; Yuen, 2007). Namun, temuan ini tidak konsisten dengan hasil penelitian Nasirwan (2008) yang menyatakan bahwa pengetahuan anggota dewan tentang anggaran tidak berpengaruh terhadap pengawasan APBD.

Apabila melihat kepada latar belakang pendidikan, hanya sebagian kecil anggota dewan yang menjadi sampel penelitian ini memiliki latar belakang pendidikan ekonomi khususnya akuntansi. Namun, berdasarkan pengalaman yang dimiliki dan adanya berbagai pendidikan dan pelatihan yang diikuti oleh anggota dewan, maka pengetahuan mereka tentang anggaran menjadi semakin baik. Hal ini sesuai dengan teori yang dikemukakan Indriantono dan Supomo (1999) yang menyebutkan bahwa kualitas pengetahuan dapat diperoleh dari pendidikan dan pengalaman. Artinya, pengetahuan yang tinggi akan memberikan kontribusi yang lebih baik apabila didukung pendidikan dan pengalaman yang memadai untuk bidang tugasnya. Dengan demikian, melalui kualitas pendidikan dan pengalaman yang memadai tersebut, maka pengetahuan anggota dewan tentang anggaran dalam rangka penga-wasan atau fungsi checks and balance akan semakin meningkat.

\section{Moderasi Gaya Kepemimpinan dan Pengetahuan Dewan Tentang Anggaran Terhadap Pengawasan APBD}

Hasil penelitian ini membuktikan bahwa interaksi gaya kepemimpinan dengan pengetahuan dewan tentang anggaran berpengaruh 
terhadap kinerja pengawasan APBD yang dilakukan anggota dewan. Artinya bahwa semakin baik penerapan gaya kepemimpinan pada setiap tingkatan kelembagaan DPRD dan diikuti pula dengan semakin tinggi kompetensi dewan berupa pengetahuan yang memadai tentang anggaran, maka kinerja pengawasan yang dilakukan oleh dewan semakin meningkat.

Hasil penelitian ini konsisten dengan penelitian terdahulu yang dilakukan (Brownell, 1983; Swieringa et al., 1992; Hugo et al., 2009) yang membuktikan bahwa gaya kepemimpinan initiating structure (orientasi tugas) dan consideration (orientasi hubungan manusia) memi-liki efek positif terhadap dorongan peningkatan pengetahuan anggota melalui learning organisasi dan berkontribusi positif terhadap peningkatan kinerja. Dalam konteks ini lebih difokuskan pada kinerja pengawasan keuangan daerah (APBD) yang dilakukan oleh lembaga DPRD. Hasil temuan ini juga konsisten dengan teori kepemimpinan yang dikemukakan Senge (1990) bahwa pengetahuan yang tinggi dapat meningkatkan kualitas hasil pekerjaan apabila didukung dengan penerapan gaya kepemimpinan yang baik. Namun, hasil penelitian ini tidak konsisten dengan dengan hasil penelitian oleh Amrul dan Nasir (2002) serta Sumarno (2005) yang menunjukkan bahwa variabel gaya kepemimpinan tidak dapat memengaruhi hubungan antara partisipasi anggaran dengan kinerja manajerial.

Fakta empiris akan pentingnya penerapan gaya kepemimpinan yang baik dalam rangka peningkatan kinerja pengawasan oleh anggota dewan, terbukti dari penilaian positif yang diberikan oleh sebagian besar sampel anggota dewan dalam penelitian ini, yaitu menyatakan bahwa pemimpin pada lembaga DPRD telah menerapkan gaya kepemimpinan orientasi tugas dan orientasi hubungan. Sehubungan dengan hal itu, tidak dapat dipungkiri bahwa faktor politis berupa isu disintegrasi bangsa, tingginya krisis kepemimpinan di Papua serta kepentingan kedudukan dan jabatan diduga merupakan faktor dominan yang turut memengaruhi 
para pimpinan organisasi publik termasuk lembaga DPRD untuk mengoptimalkan peranan kepemimpinannya. Menyadari akan pentingnya aspek kepemimpinan dalam rangka meningkatkan kinerja DPRD khususnya kinerja pengawasan anggaran, maka implementasi gaya kepemimpinan yang baik pada lembaga DPRD turut diterapkan.

Apabila para pimpinan DPRD mampu mengarahkan lembaga DPRD pada kinerja pengawasan secara optimal, maka pimpinan DPRD dapat dimungkinkan untuk memperoleh imbalan berupa reputasi yang lebih baik di masyarakat yang kemudian dimungkinkan untuk dapat terpilih kembali. Hal ini senada dengan aplikasi teori keagenan yang dikemukakan oleh Suwardjono (2005:485) bahwa untuk menciptakan kontrak kerja yang fairness antara agen (DPRD) dan prinsipal (rakyat), maka agen bertindak atas nama dan untuk kepentingan prinsipal, dan berdasarkan pelaksanaan kewajiban yang optimal kepada prinsipal, maka agen akan mendapatkan insentif/ yang memuaskan dari prinsipal.

\section{Moderasi Akuntabilitas dan Pengetahuan Dewan Tentang Anggaran Terhadap Pengawasan APBD}

Hasil penelitian ini membuktikan bahwa interaksi pengetahuan tentang anggaran dengan akuntabilitas tidak berpengaruh terhadap penga-wasan APBD yang dilakukan anggota dewan. Temuan ini konsisten dengan hasil penelitian oleh Palupi (2011). Dalam penelitiannya tidak dapat dibuktikan bahwa akuntabilitas memiliki pengaruh terhadap kinerja pemerintah. Di samping itu, temuan ini bertentangan dengan hasil penelitian Sopanah dan Wahyudi (2007) Coryanata (2007) serta Pramita dan Andriyani (2010) yang membuktikan bahwa akuntabilitas kepada publik dapat memperkuat hubungan antara pengetahuan dewan tentang anggaran dengan pengawasan APBD.

Peneliti menduga, perbedaan hasil ini dipengaruhi karena ketika dewan merespon stimuli yang diterima berdasarkan objek pemersepsi dalam hal ini adalah adanya akuntabilitas kepada publik namun stimuli yang diterima tidak berpengaruh terhadap perilaku dewan dalam melak- 
sanakan fungsi pengawasan. Artinya, anggota dewan menyadari akan pentingnya penyelenggaraan akuntabilitas kepada publik dalam rangka meningkatkan pengawasan APBD. Namun, berdasarkan pengalaman dan kondisi yang terjadi, dewan merespon bahwa ada tidaknya penyelenggaraan akuntabilitas kepada publik meskipun diiringi pula dengan adanya peningkatan kompetensi anggota dewan berupa pengetahuan yang memadai tentang anggaran, tidak akan berdampak banyak terhadap fungsi pengawasan APBD yang dilakukan oleh dewan. Hal ini sesuai dengan teori yang dikemukakan Robbbins (2001:46) bahwa faktor utama yang memengaruhi persepsi antara satu individu dengan individu lain adalah faktor situasi, yaitu berupa keadaan sosial dan faktor pemersepsi, yaitu berupa pengalaman yang dialami.

Pada kenyataannya, anggota dewan dalam merespon akuntabilitas yang dilakukan oleh pemerintah daerah (eksekutif) berbedabeda, salah satunya disebabkan seringnya keterlambatan penyampaian LAKIP secara periodik, di samping masih terdapatnya anggota dewan yang tidak mengetahui standar operasional prosedur akuntabilitas yang dilakukan lembaga eksekutif. Penyelenggaraan akuntabilitas sebagai media pertanggungjawaban atas keberhasilan atau kegagalan kinerja keuangan dan kinerja non keuangan eksekutif, yang hasil dan manfaatnya harus benar-benar dirasakan masyarakat, sebagian anggota dewan menilai meragukan hal tersebut.

Peneliti sependapat dengan pandangan Werimon (2005) bahwa akuntabilitas kepada publik di Papua masih dalam tahap wacana dan implementasinya masih dalam tahap formalitas. Hal ini dibuktikan dengan maraknya demonstrasi yang sering dilakukan oleh berbagai elemen mahasiswa di Papua, baik yang berada di Papua maupun luar Papua yang menuntut adanya akuntabiltas dan transparansi dari kebi-jakan publik. Tingginya angka penyimpangan anggaran, rendahnya penyerapan anggaran, serta kurangnya penegakan atas kriteria efekti- 
vitas dan efisiensi dalam penyelenggaraan anggaran juga masih merupakan masalah rendahnya akuntabilitas di Papua.

Selama ini pemerintah lebih berorientasi pada akuntabilitas terhadap pemerintah di atasnya (pusat), akan tetapi belum sepenuhnya berpihak kepada masyarakat yang dilayani. Akibatnya, tuntutan tanggung jawab pemerintah atas minimnya kesejahteraan masyarakat asli Papua masih menjadi permasalahan utama saat ini. Hal tersebut ditunjukkan dengan Indeks Pembangunan Manusia Papua yang berada pada urutan paling terendah dibandingkan 32 Provinsi lain di Indonesia (BPS, 2012), sementara APBD Papua berada dalam kerangka otonomi khusus sebagai bentuk kebijakan pemerintah pusat dalam rangka mendorong percepatan pembangunan di Papua semenjak tahun 2001. Oleh karenanya, meski semakin tinggi pengetahuan anggota dewan tentang anggaran, namun tidak diikuti pula dengan adanya penyelenggaraan akuntabilitas yang dampaknya dapat benar-benar dirasakan oleh rakyat secara nyata, maka pengawasan APBD yang dilakukan oleh dewan hanya sebatas retorika.

\section{Moderasi Partisipasi Masyarakat dan Pengetahuan Dewan Tentang Anggaran Terhadap Pengawasan APBD}

Hasil penelitian ini membuktikan bahwa interaksi antara pengetahuan anggaran dengan partisipasi masyarakat berpengaruh terhadap pengawasan APBD yang dilakukan oleh anggota dewan. Artinya bahwa bila semakin tinggi partisipasi publik/masyarakat dalam pengelolaan APBD dan diikuti pula dengan semakin tinggi pengetahuan anggota dewan tentang anggaran, maka fungsi pengawasan APBD yang dilakukan oleh anggota dewan akan semakin meningkat.

Temuan ini konsisten dengan hasil penelitian oleh Coryanata (2007); Basri (2008); dan Mayasari (2012) yang membuktikan bahwa interaksi antara kualitas anggota dewan yang diukur dari pendidikan, pelatihan, pengalaman dan pengetahuan dengan partisipasi masyarakat mempunyai pengaruh terhadap pengawasan APBD. Hasil penelitian ini 
juga konsisten dengan teori-teori yang mendukung bahwa jika masyarakat dilibatkan di dalam proses penganggaran, pengawasan yang dilakukan oleh dewan akan semakin meningkat (Achmadi et al., 2002: 74; Anthony dan Govindarajan, 2005:86; Rubin, 1996).

Namun, hasil penelitian ini bertentangan dengan hasil penelitian Sopanah dan Wahyudi (2007) yang menggunakan dua sampel, yaitu sampel anggota dewan dan masyarakat. Hasil penelitian dengan menggunakan sampel masyarakat menunjukkan bahwa interaksi an-tara partisipasi masyarakat dengan pengetahuan anggota dewan tidak berpengaruh terhadap pengawasan APBD. Hal tersebut diduga karena sampel yang digunakan yaitu sampel masyarakat. Artinya, masyarakat saat ini yang merasa lebih diwakili oleh LSM dan praktisi menyatakan bahwa ada tidaknya penyelenggaraan partisipasi rakyat tidak akan berdampak terhadap pengawasan yang dilakukan oleh anggota dewan.

\section{Moderasi Transparansi dan Pengetahuan Dewan Tentang Anggaran Terhadap Pengawasan APBD}

Hasil penelitian ini membuktikan bahwa interaksi antara transparansi kebijakan publik dengan pengetahuan dewan tentang anggaran tidak berpengaruh terhadap pengawasan APBD. Temuan ini tetap konsisten dengan hasil penelitian oleh Sopanah dan Mardiasmo (2003) yang telah membuktikan bahwa interaksi antara pengetahuan dewan tentang anggaran dan transparansi kebijakan publik tidak berpengaruh terhadap pengawasan dewan pada keuangan daerah (APBD). Namun, hasil temuan ini tidak konsisten dengan hasil penelitian oleh Coryanata (2007) yang membuktikan bahwa interaksi antara transparansi kebija-kan publik dengan pengetahuan dewan tentang anggaran berpengaruh terhadap pengawasan APBD. Peneliti sependapat dengan pandangan Werimon (2005) dan Basri (2008) bahwa transparansi kebijakan publik di Papua masih dalam taraf retorika dan implementasinya masih dalam tahap formalitas. Akses terhadap kebijakan publik masih sulit dan hanya orang-orang tertentu yang bisa mendapatkannya. 
Peneliti menduga perbedaan hasil ini disebabkan adanya perbedaan terhadap budaya yang sudah tercipta dalam pemerintahan dan legislatif yang sulit untuk melakukan transparansi kepada publik. Hasil studi GDS (Governance and Decentralization Suvey) tahun 2002 oleh Pusat Studi Kependudukan dan Kebijakan (PSKK) UGM menemukan bahwa ketertutupan dalam pembahasan RAPBD ditemukan pada banyak daerah. Persoalan menyangkut rincian alokasi dana APBD pada setiap sektor dan progam/kegiatan tidak pernah secara terbuka dipublikasikan secara luas kepada masyarakat. Di samping itu, tidak dijumpainya bentuk mekanisme atau kegiatan yang memberikan kesempatan pada publik di daerah untuk turut mencermati, mengkritisi atau mengevaluasi rincian alokasi dan penggunaan dana dalam APBD. Penentuan alokasi dan distribusi setiap kegiatan mutlak hanya ditentukan oleh eksekutif dan DPRD secara tertutup atau dalam istilah politiknya disebut insiders game (Gedeona, 2005:250).

Hasil penelitian oleh Indonesian Corruption Watch (ICW) dalam Gedeona (2005) dan hasil studi Public Expenditure Analysis (PEA) Papua tahun 2004 telah menunjukkan bahwa ketiadaan aspek transparansi dalam pengelolaan anggaran akan menimbulkan beberapa modus kejahatan korupsi di APBD, yaitu: penipuan terhadap anggaran; menciptakan anggaran baru; mark up anggaran; pembuatan anggaran tanpa perincian; dan menghilangkan pos anggaran dengan cara melebihkan anggaran berbagai tunjangan dewan. Apabila kita berpijak kepada filosofi anggaran daerah, dapat dikatakan bahwa telah terjadi penyimpangan secara prosedural teknis yang cukup berarti. Dengan demikian, meskipun semakin tinggi pengetahuan anggota dewan tentang anggaran, namun tidak diikuti pula dengan keterbukaan akses informasiinformasi anggaran terhadap rakyat secara nyata, terutama mengenai penentuan alokasi dan distribusi setiap kegiatan anggaran yang mutlak hanya ditentukan oleh eksekutif dan legislatif secara ter-tutup, maka pengawasan APBD oleh dewan hanya sebatas retorika. 


\section{KESIMPULAN DAN SARAN}

\section{Kesimpulan}

Berdasarkan hasil analisis pengujian hipotesis, terdapat bebe-rapa simpulan yang dapat diambil dari penelitian ini.

a. Penelitian ini membuktikan bahwa pengetahuan anggota dewan tentang anggaran berpengaruh terhadap pengawasan APBD.

b. Interaksi antara pengetahuan dewan tentang anggaran dengan gaya kepemimpinan juga berpengaruh terhadap pengawasan APBD.

c. Hasil penelitian ini tidak dapat membuktikan bahwa interaksi antara pengetahuan dewan tentang anggaran dengan akuntabilitas publik berpengaruh terhadap pengawasan APBD.

d. Interaksi antara pengetahuan dewan tentang anggaran dengan partisipasi masyarakat berpengaruh terhadap pengawasan APBD.

e. Interaksi antara pengetahuan dewan tentang penganggaran dengan transparansi kebijakan publik tidak berpengaruh terhadap pengawasan APBD.

\section{Saran}

Dalam penelitian ini terdapat saran-saran yang dapat dijadikan rekomendasi guna pengembangan penelitian sejenis di masa datang.

a. Bagi Penelitian selanjutnya agar jumlah sampel dapat diperluas ke anggota dewan pemerintah kota dan pemerintah kabupaten dalam skala satu provinsi sehingga hasil penelitian ini dapat digeneralisasi.

b. Pada saat pengambilan sampel, penelitian selanjutnya hendaknya memilih sampel anggota dewan yang secara khusus membidangi anggaran.

c. Peneliti selanjutnya perlu mempertimbangkan variabel kontinjensi lainnya, terutama yang diharapkan dapat memperkuat atau memperlemah hubungan antara pengetahuan anggota dewan tentang anggaran dengan pengawasan dewan pada APBD. 


\section{DAFTAR PUSTAKA}

Abdullah, Syukriy dan John Andra Asmara. 2006. Perilaku Opportunistik Legislatif dalam Penganggaran Daerah. Simposium Nasional Akuntansi IX, Padang.

Basri, Yesi Mutia. 2008. Pengaruh pengetahuan dewan tentang anggaran pada pengawasan keuangan daerah. Jurnal IImu Administrasi Negara, vol. 8, nomor 1:29-39.

Ceicilia Engko dan Gudono. 2007. Pengaruh Kompleksitas Tugas dan Locus of Control terhadap Hubungan antara Gaya Kepemimpinan dan Kepuasan Kerja Auditor, Simposium Nasional Akuntansi $X$. Makasar.

Coryanata, Isma. 2007. Akuntabilitas, Partisipasi Masyarakat, dan Transparansi Kebijakan Publik sebagai Pemoderating Hubungan Pengetahuan Dewan tentang Anggaran dan Pengawasan Keuangan Daerah (APBD). Simposium Nasional Akuntansi X. Makasar.

Fatchurrochman, Agam. 2002. Manajemen Keuangan Publik, Materi Pelatihan Anti Korupsi, Indonesian Coruption Watch, 23-25 Januari 2002, Jakarta.

Gede, Putu. Penyelidikan Dugaan Korupsi Pimpinan DPRD Kabupaten Jayapura. (Online) http://www.kbr68h.com/ (diakses 30 September 2011)

Ghozali, Imam. 2005. Aplikasi Analisis Multivariate Dengan Program SPSS, Badan Penerbit Universitas Diponegoro. Semarang.

Hugo, Zagorsek., Vlado Dimovski., Miha Skerlavaj. 2009. Transactional and Transformational Leadership Impacts on Organizational Learning. JEEMS, Vol. 2. pp.145-165.

Krina, Loina Lalolo. 2003. Indikator dan Alat Ukur Prinsip Akuntabilitas, Transparansi dan Partisipasi. Seminar pada Sekretariat Good Public Governance. BAPPENAS. Jakarta.

Mampioper, Dominggus. 2009. Kualitas Caleg dan Pemilu 2009-2014 di Papua. (Online) http://tab-loidjubi.com/index.php (diakses 7 September 2012).

Mardiasmo. 2002. Otonomi dan Manajemen Keuangan Daerah, Andi Publisher, Yogyakarta. 
Mardiasmo. 2004. Membangun Akuntabilitas Publik Keuangan Negara. Majalah Media Akuntansi, Edisi No. 39.

Pramita, Yulinda Devi dan Andriyani, lilik, 2010. Determinasi hubungan pengetahuan dewan tentang anggaran dengan pengawasan dewan pada APBD. Simposium Nasional Akuntansi XIII, Purwokerto.

Rosseptalia, Rima. 2006. Pengaruh Pengetahuan Dewan Tentang Anggaran Terhadap Pengawasan Keuangan Daerah Dengan Variabel Moderator Partisipasi Masyarakat Dan Transparansi Kebijakan Publik, Skripsi, Universitas Islam Indonesia, Yogyakarta.

Sedarmayanti. 2009. Reformasi Administrasi Publik, Reformasi Birokrasi dan Kepemimpinan Masa Depan, PT Refika Aditama, Bandung.

Sopanah dan Mardiasmo. 2003. Pengaruh Partisipasi Masyarakat dan Transparansi Kebijakan Publik terhadap hubungan antara Pengetahuan Dewan tentang Anggaran dengan Pengawasan Keuangan Daerah (APBD). Simposium Nasional Akuntansi VI. Surabaya.

Sopanah dan Wahyudi, Isa. 2007. Pengaruh Akuntabilitas Publik Partisipasi Masyarakat dan Transparansi Kebijakan Publik Terhadap Hubungan Antara Pengetahuan Anggaran Dengan Pengawasan Keuangan Daerah (APBD). UMM Scientific Journal, ejournal.umm.ac.id. (diakses pada tanggal 5 Maret 2012). 